\title{
Protein $O$-N-Acetylglucosaminylation Modulates Promoter Activities of Cyclic AMP Response Element and Activator Protein 1 and Enhances E-Selectin Expression on HuH-7 Human Hepatoma Cells
}

\author{
Yutaro Azuma, * Kana Miura, Koji Higai, and Kojiro Matsumoto \\ Department of Clinical Chemistry, School of Pharmaceutical Sciences, Toho University; 2-2-1 Miyama, Funabashi, Chiba \\ 247-8510, Japan. Received June 25, 2007; accepted September 5, 2007; published online October 3, 2007
}

\begin{abstract}
High glucose accelerates $O$-N-acetylglucosaminylation $(O$-GlcNAcylation) of proteins and causes diabetic complications. In the present study, we found that treatment of HuH-7 human hepatoma cells with high glucose or the protein $O$-N-acetylglucosaminidase $(O$-GlcNAcase) inhibitor $O$-(2-acetoamide-2-deoxy-D-glucopyranosylidene)amino-N-phenylcarbamate (PUGNAc) increased the cell surface expression of E-selectin. A dual luciferase reporter assay indicated that high glucose and PUGNAc suppressed promoter activities of the cyclic AMP response element (CRE) and enhanced those of activator protein 1 (AP-1). Enhanced CRE promoter activities in HuH-7 cells treated with dibutyryl cAMP or co-transfected with a protein kinase A expression vector pFC-PKA that enhances the phosphorylation of CRE binding protein (CREB) were suppressed by PUGNAc. In contrast, PUGNAc further increased the enhanced AP-1 promoter activity in cells transfected with a mitogen-activated protein kinase kinase kinase expression vector pFC-MEKK that enhances c-Jun phosphorylation. Immunoblotting using an anti- $O$-GIcNAc antibody revealed that high glucose and PUGNAc accelerated protein $O$ GlcNAcylation and that there were substantial differences in the $O$-GlcNAcylated proteins in the cytoplasmic and nuclear fractions. In addition, PUGNAc increased the nuclear import of $O$-GlcNAcylated CREB. These results suggest that protein $\boldsymbol{O}$-GIcNAcylation modulates the promoter activities of $E$-selectin gene, suppression of CRE and enhancement of AP-1, and enhances E-selectin protein expression on hepatocytes.
\end{abstract}

Key words cyclic AMP response element (CRE); activator protein 1; CRE binding protein; E-selectin; $O$-(2-acetoamide-2deoxy-D-glucopyranosylidene)amino-N-phenylcarbamate; protein $O$-N-acetylglucosaminylation

A variety of cytoplasmic and nuclear proteins, including transcription factors, cytoskeletal proteins, nuclear pore proteins, and oncogene products, can be modified on serine and threonine residues by $O$-linked $\beta$-N-acetylglucosamine $(O$ GlcNAc). ${ }^{1,2)}$ This post-translational modification is dynamic and inducible and occurs at sites similar and adjacent to phosphorylation sites that are thought to influence protein functions. Therefore, regulation by $O$-GlcNAcylation is thought to compete with regulation by phosphorylation/dephosphorylation. Furthermore, nuclear transport of proteins is reported to be regulated by the balance of $O$-GlcNAcylation and phosphorylation. ${ }^{3)}$ These findings suggest that protein $O$-GlcNAcylation plays an important role in signal transduction and cellular function.,5)

Protein $O$-GlcNAcylation is catalyzed by $O$-GlcNAc transferase (OGT) using uridine diphosphate (UDP)-GlcNAc as a donor substrate. The transferred $O$-GlcNAc is reversed by $O$ GlcNAc hexosaminidase (O-GlcNAcase) ${ }^{6}{ }^{6}$ UDP-GlcNAc is generated intracellularly from glucose by the hexosamine biosynthesis pathway, wherein glutamine fructose-6-phosphate amidotransferase (GFAT) is a rate-limiting enzyme. Therefore, protein $O$-GlcNAcylation is regulated by the cellular levels of OGT, $O$-GlcNAcase, GFAT, and glucose. ${ }^{7)}$

Hyperglycemia enhances the levels of UDP-GlcNAc and protein $O$-GlcNAcylation, and perturbations in the regulation of protein $O$-GlcNAcylation have been implicated in diabetes mellitus, cancer, and neurodegenerative diseases. ${ }^{8)}$ Serum concentrations of soluble adhesion molecules such as soluble endothelial leukocyte adhesion molecule (ELAM-1, E-selectin), intercellular adhesion molecule-1 (ICAM-1), and vascular cell adhesion molecule-1 (VCAM-1) are related to the degree of insulin resistance and hyperglycemia in patients with type 2 diabetes. ${ }^{9,10)}$ Incubation of human umbilical vein endothelial cells (HUVEC) in culture media containing high glucose enhances the expression of cell surface adhesion molecules through a process that involves nuclear factor- $\kappa \mathrm{B}$ $(\mathrm{NF}-\kappa \mathrm{B}),{ }^{11)}$ protein kinase $\mathrm{C},{ }^{12-14)}$ and poly ADP ribose polymerase, ${ }^{15)}$ although the precise mechanism remains to be elucidated. In a previous report, ${ }^{16)}$ we demonstrated that glycated human serum albumin enhanced E-selectin expression on HUVEC by NF- $\kappa \mathrm{B}$ and activator protein-1 (AP-1) via NADPH oxidase activation. In type 2 diabetes and the metabolic syndrome, hepatocellular inflammation by hepatic steatosis was also associated with the development of local and systemic insulin resistance. ${ }^{17,18)}$

It has been established that pro-inflammatory cytokines such as interleukin- $\beta$ (IL- $1 \beta$ ) and tumor necrosis factor- $\alpha$ (TNF- $\alpha$ ) enhance the expression of these adhesion molecules, although there are different patterns of expression among them. ${ }^{19)}$ The organization of the cytokine-inducible element in the E-selectin expression promotor requires NF$\kappa \mathrm{B}$, activating transcription factor-2 (ATF-2), and high mobility group protein (HMG) I(Y) for induction and these interact as a unit with the basal transcriptional machinery. The ATF site is identified as a functional element for maximal cytokine-induced expression of E-selectin gene, which can bind c-Jun $^{20)}$ and the cyclic AMP responsive element (CRE) binding protein (CREB) ${ }^{21)}$ and changes in the level of induced Eselectin expression can be correlated with alterations in binding of c-Jun or CREB to ATF. ${ }^{21)}$

In this study, we focused on the role of protein $O-\mathrm{GlcNA}$ cylation in the cell surface expression of E-selectin and investigated whether high glucose and a nontoxic $O$-GlcNAcase inhibitor $O$-(2-acetoamide-2-deoxy-D-glucopyra- 
nosylidene) amino-N-phenylcarbamate (PUGNAc) ${ }^{22,23)}$ modulate E-selectin expression on $\mathrm{HuH}-7$ human hepatoma cells. Our results suggest that protein $O$-GlcNAcylation modulates the promoter activities of CRE and activation protein-1 (AP1) and enhances E-selectin protein expression on hepatocytes.

\section{MATERIALS AND METHODS}

Human Cell Lines Human hepatoma cell lines HuH-7 cells were purchased from the Japanese Collection of Research Bioresources Cell Bank (Tokyo, Japan) and cultured in Dulbecco's modified Eagle's medium (Nissui Pharmaceutical Co., Tokyo, Japan) supplemented with $10 \%$ heat-inactivated fetal bovine serum (JRH Biosciences, Lenexa, KS, U.S.A.), $0.6 \mathrm{mg} / \mathrm{ml}$ L-glutamate (Wako Pure Chemical, Osaka, Japan), $100 \mathrm{U} / \mathrm{ml}$ penicillin (Banyu Pharmaceutical Co., Tokyo, Japan), and $100 \mu \mathrm{g} / \mathrm{ml}$ streptomycin (Meiji Seika Co., Tokyo, Japan) in a humidified atmosphere containing $5 \% \mathrm{CO}_{2}$ at $37^{\circ} \mathrm{C}$.

Determination of Cell Surface E-Selectin Levels on HuH-7 Cells HuH-7 cells $\left(5 \times 10^{4} / \mathrm{ml}\right)$ cultured for $24 \mathrm{~h}$ in a 96-well plate were treated with $5-33 \mathrm{~mm}$ glucose or 0 $100 \mu \mathrm{M}$ PUGNAc (Carbogen, Aarau, Switzerland) at $37^{\circ} \mathrm{C}$ for $0-48 \mathrm{~h}$. HuH-7 cells were also stimulated with $100 \mathrm{U} / \mathrm{ml}$ IL-1 $\beta$ (Genzyme, Cambridge, MA, U.S.A.) at $37^{\circ} \mathrm{C}$ for $24 \mathrm{~h}$ in the absence or presence of $33 \mathrm{~mm}$ glucose or $100 \mu \mathrm{M}$ PUGNAc. After washing three times with PBS, the cells were fixed by treating them with $1 \%$ formalin in PBS for $1 \mathrm{~h}$. The cells were washed five times with PBS then incubated at room temperature for $1 \mathrm{~h}$ with $1 \mu \mathrm{g} / \mathrm{ml}$ mouse anti-E-selectin antibody (R\&D Systems Inc., Minneapolis, MN, U.S.A.) in PBS containing $1 \% \mathrm{BSA}$ and $0.1 \% \mathrm{NaN}_{3}$. After washing five times with PBS, the cells were incubated at room temperature for $1 \mathrm{~h}$ with $1 \mu \mathrm{g} / \mathrm{ml}$ peroxidase (POD)-conjugated antimouse IgG and IgM antibody (Jackson ImmunoResearch Laboratories, West Grove, PA, U.S.A.) in PBS containing 1\% BSA. After washing five times with PBS, POD activities were determined using a TMB 1 Component HRP kit (BioFX Laboratories, Owing Mills, MD, U.S.A.). The reaction was stopped by adding $1 \mathrm{M} \mathrm{H}_{2} \mathrm{SO}_{4}$, and the absorbance at $450 \mathrm{~nm}$ was determined using a MRP-A4i II micro plate reader (TOSOH Co., Tokyo, Japan).

Immuno Blotting Analysis of $\boldsymbol{O}$-GlcNAcylated Proteins HuH-7 cells $\left(5 \times 10^{5} / \mathrm{ml}\right)$ were cultured for $24 \mathrm{~h}$ in a 6 -well plate and then treated with $33 \mathrm{~mm}$ glucose or $100 \mu \mathrm{M}$ PUGNAc at $37^{\circ} \mathrm{C}$ for $24 \mathrm{~h}$. The cells were detached with $0.02 \%$ EDTA in PBS, washed with PBS, and suspended in $50 \mathrm{~mm}$ Tris- $\mathrm{HCl}$ (pH 8.0) containing 1\% NP-40, 0.2 mm EDTA, and $2 \mu \mathrm{M}$ PUGNAc. After freezing and thawing, the cells were sonicated on ice for $15 \mathrm{~s}$, and the solution was centrifuged at $10000 \times \boldsymbol{g}$ for $5 \mathrm{~min}$.

Cytoplasmic and nuclear extracts were prepared according to Lefebvre et al. ${ }^{24)}$ Briefly, HuH-7 cells $\left(1.0 \times 10^{6}\right)$ were suspended in PBS containing $500 \mu \mathrm{g} / \mathrm{ml}$ digitonin (Sigma Aldrich Co., St. Louis, MO, U.S.A.) and $1 \mathrm{~mm}$ phenylmethylsulfonyl fluoride (PMSF) (Sigma Aldrich) at $37^{\circ} \mathrm{C}$ for $10 \mathrm{~min}$. Cytoplasmic extracts were obtained by centrifugation at $200 \times \boldsymbol{g}$ at $4{ }^{\circ} \mathrm{C}$ for $10 \mathrm{~min}$. Precipitates were washed with PBS, resuspended in PBS containing $0.5 \%$ Triton $\mathrm{X}-100$ and $1 \mathrm{~mm}$ PMSF, and centrifuged at $800 \times \boldsymbol{g}$ at $4{ }^{\circ} \mathrm{C}$ for $10 \mathrm{~min}$.
Precipitates were suspended in $50 \mathrm{~mm}$ HEPES (pH 7.4) containing $2 \%$ Triton $\mathrm{X}-100,500 \mathrm{~mm} \mathrm{NaCl}$, and $1 \mathrm{~mm}$ PMSF, and nuclear extracts were obtained by sonicating the suspension three times for $10 \mathrm{~s}$ on ice. To prevent the detachment of $O$-GlcNAc from proteins during sample preparation, we added $2 \mu \mathrm{M}$ PUGNAc to all solutions.

The resulting supernatant was mixed with an equal volume of $2 \times$ SDS-PAGE sample buffer, boiled for $5 \mathrm{~min}$, and separated by $12.5 \%$ SDS-PAGE. The proteins were electrophoretically transferred to a Hybond-P PVDF membrane (Amersham Bioscience, Piscataway, NJ, U.S.A.). The membrane was blocked with Blocking One solution (Nacalai Tesque, Kyoto, Japan) and washed three times with $0.1 \%$ Tween 20 in PBS (PBS-T). The membrane was then incubated with mouse anti-O-GlcNAc monoclonal antibody (IgM, $1: 1000$ ) (Pierce Biotechnology, Rockford, IL, U.S.A.) in PBS-T at room temperature for $1 \mathrm{~h}$. After washing three times with PBS-T, the membrane was incubated with POD-conjugated goat anti-mouse IgM antibody $(1: 10000)$ (Amersham Bioscience) in PBS-T at room temperature for $1 \mathrm{~h}$. The membrane was then washed three times with PBS-T, and proteins were incubated with ECL plus (Amersham Bioscience) at room temperature for $5 \mathrm{~min}$ and analyzed with a Bioimager Strom $^{\text {TM }} 830$ (Amersham Bioscience). Protein levels were determined using the Bio-Rad Protein Assay (Bio-Rad Laboratories, Hercules, CA, U.S.A.), with BSA as a standard.

Immuno-Precipitation of CRE Binding Protein (CREB) Protein A/G PLUS-agarose $60 \mu \mathrm{l}$ (Santa Cruz Biotechnology, Santa Cruz, CA, U.S.A.) was incubated at room temperature for $1 \mathrm{~h}$ with rabbit anti-CREB antibody (IgG, $1: 1000)$ (Upstate Biotechnology Inc., Lake Placid, NY, U.S.A.) in PBS then washed three times with PBS. The antiCREB antibody-coated beads were then mixed with cytoplasmic or nuclear extracts $(1 \mu \mathrm{g} / \mu \mathrm{l}$ protein $)$ at room temperature for $3 \mathrm{~h}$ then washed three times with PBS and mixed with an equal volume of sample buffer (10\% glycerol, $2 \%$ sodium dodecyl sulfate, and $1 \%$ bromophenol blue in $50 \mathrm{mmol} / 1$ Tris- $\mathrm{HCl}, \mathrm{pH} \mathrm{6.5)}$ and then boiled for $5 \mathrm{~min}$. The eluted proteins were then separated by $15 \%$ SDS-PAGE and analyzed by immuno-blotting as described above (see "Immuno-blotting analysis of $O$-GlcNAcylated proteins") using mouse anti-GlcNAc monoclonal antibody, rabbit anti-CREB antibody, or mouse anti-phospho-CREB monoclonal antibody (IgM, $1: 1000$ ) (Upstate Biotechnology, Inc.) in PBS-T as a primary antibody and POD-conjugated donkey anti-rabbit IgG antibody (Amersham Biosciences) or POD-conjugated anti-mouse $\operatorname{IgG}+\operatorname{IgM}$ antibody as a secondary antibody.

Dual Luciferase Assay Reporter plasmids for CRE (pCRE-Luc) and AP-1 (pAP-1-Luc), which contain multiple copies of typical CRE and AP-1 binding sequences, respectively, a cAMP-dependent protein kinase (PKA) expression plasmid (pFC-PKA), and a mitogen-activated protein (MAP) kinase kinase kinase (MEKK) expression plasmid ( $\mathrm{pFC}$ MEKK) were purchased from Stratagene (La Jolla, CA, U.S.A.).

For estimation of CRE and AP-1 promoter activities, $\mathrm{HuH}-7$ cells were cotransfected with $0.1 \mu \mathrm{g}$ of a Renilla luciferase expression vector pRL-CMV (Promega, Madison, WI, U.S.A.) as an internal control for total cellular transcription along with pCRE-Luc or pAP-1-Luc $(1 \mu \mathrm{g})$ using Lipo- 
fectamine 2000 (Invitrogen). Transfected HuH-7 cells $\left(2 \times 10^{4}\right.$ cells $\left./ \mathrm{ml}\right)$ in a 48 -well plate were treated with $33 \mathrm{~mm}$ glucose or $100 \mu \mathrm{M}$ PUGNAc for $24 \mathrm{~h}$. Firefly and Renilla luciferase activities were determined using a Dual-Luciferase Reporter Assay System and 20/20n luminometer (Promega). To calculate the relative luciferase activities, the firefly luciferase activities were normalized by the corresponding $R e$ nilla luciferase activities.

For estimation of PKA-induced CRE or MEKK-induced AP-1 promoter activities, HuH-7 cells co-transfected with pCRE-Luc $(1 \mu \mathrm{g})$ and pFC-PKA (10 ng) or with pAP-1-Luc $(1 \mu \mathrm{g})$ and $\mathrm{pFC}-\mathrm{MEKK}(10 \mathrm{ng})$, respectively, were treated with $100 \mu \mathrm{M}$ PUGNAc for $24 \mathrm{~h}$. For cAMP-dependent PKAinduced CRE promoter activity, HuH-7 cells transfected with pCRE-Luc $(1 \mu \mathrm{g})$ were treated with $100 \mu \mathrm{M}$ PUGNAc for $24 \mathrm{~h}$ and stimulated with $100 \mu \mathrm{M}$ dibutyryl cAMP (SigmaAldrich) at $37^{\circ} \mathrm{C}$ for $3 \mathrm{~h}$. These cells were co-transfected with pRL-CMV and subjected to the dual luciferase assay described above.

\section{RESULTS}

High Glucose and PUGNAc Accumulate $O$-GlcNAcylated Proteins in HuH-7 Cells Protein $O$-GlcNAcylation is regulated by OGT and GlcNAcase activities as well as the intracellular concentration of the donor substrate, UDP-GlcNAc. UDP-GlcNAc is synthesized from glucose via the hexosamine biosynthetic pathway, in which GFAT is a rate-limiting enzyme. Therefore we determined the levels of GFAT, OGT, and GlcNAcase mRNA in human hepatoma HuH-7 cells by RT-PCR. These genes were ubiquitously expressed in HuH-7 cells (data not shown).

Then, we treated $\mathrm{HuH}-7$ cells with $33 \mathrm{~mm}$ glucose or $100 \mu \mathrm{M}$ PUGNAc for $24 \mathrm{~h}$ and analyzed $O$-GlcNAcylated

(A)

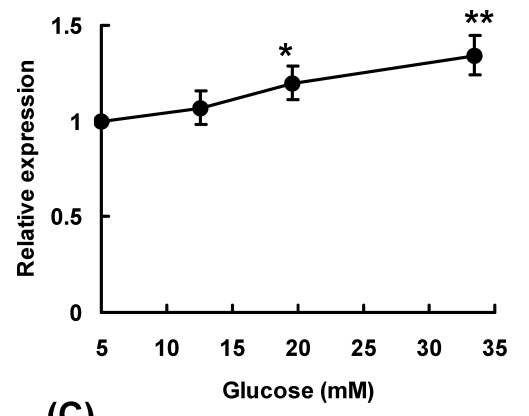

(C)

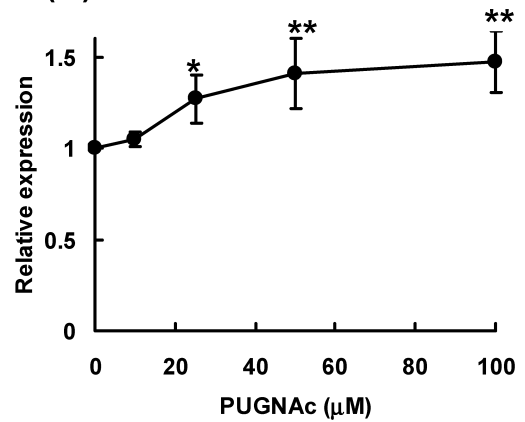

proteins by immuno-blotting with anti- $O$-GlcNAc antibody (Fig. 1). Many protein bands were immuno-blotted in whole cell lysate from HuH-7 cells cultured in $5 \mathrm{~mm}$ glucose (control). Treatment with $33 \mathrm{~mm}$ glucose and $100 \mu \mathrm{M}$ PUGNAc further accumulated $O$-GlcNAcylated proteins in the cells. Especially, PUGNAc accumulated $O$-GlcNAcylated proteins with high molecular weight.

High Glucose and PUGNAc Enhance Cell Surface Expression of E-Selectin on HuH-7 Cells To investigate the effect of high glucose and PUGNAc on E-selectin expression, we treated $\mathrm{HuH}-7$ cells with $5-33 \mathrm{~mm}$ glucose or 0 $100 \mu \mathrm{M}$ PUGNAc for $0-48 \mathrm{~h}$ and determined the levels of E-selectin on the cell surface (Fig. 2). The cell surface levels

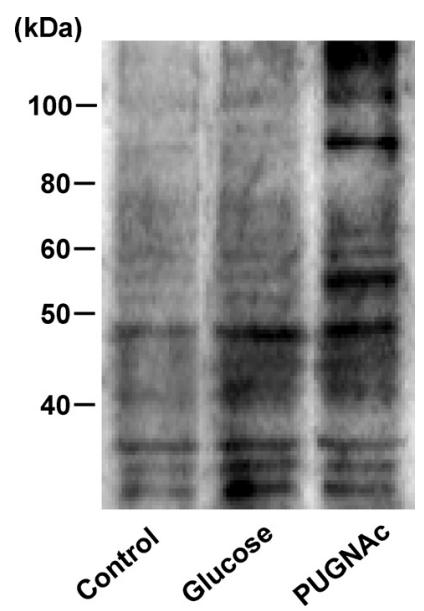

Fig. 1. $O$-GlcNAcylated Proteins Accumulated in HuH-7 Cells by Treatment with High Glucose or PUGNAc

Whole cell lysate was obtained from HuH-7 cells treated with $33 \mathrm{~mm}$ glucose or $100 \mu \mathrm{m}$ PUGNAc for $24 \mathrm{~h}$, and $O$-GlcNAcylated proteins were identified by Western blotting with an anti-O-GlcNAc antibody.

(B)

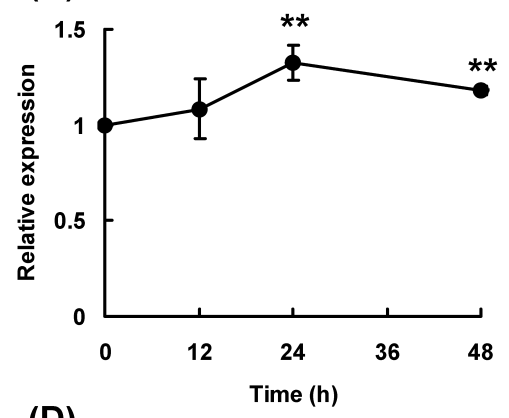

(D)

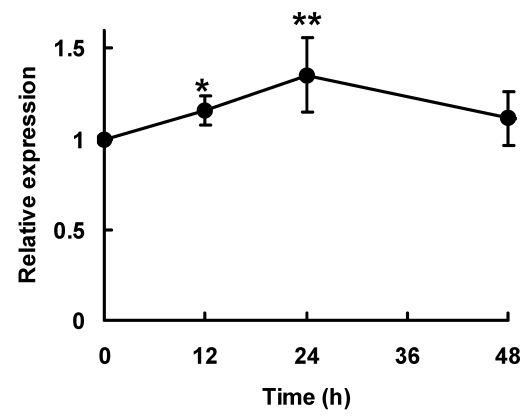

Fig. 2. Cell Surface Expression of E-Selectin in HuH-7 Cells Treated with High Glucose or PUGNAc

HuH-7 cells were treated with 5 to $33 \mathrm{~mm}$ glucose for $24 \mathrm{~h}$ (A), 33 mм glucose for 0 to $48 \mathrm{~h}$ (B), 0 to $100 \mu \mathrm{M}$ PUGNAc for $24 \mathrm{~h}$ (C), or $100 \mu \mathrm{M}$ PUGNAc for 0 to $48 \mathrm{~h}$ (D). Cell surface levels of E-selectin were determined by enzyme-linked immunoabsorbent assay using an anti-E-selectin antibody and POD-conjugated anti-mouse IgG + IgM antibody. The expression levels are shown as a ratio compared with 0 -h treatment. The results represent the means \pm S.D. $(n=4) . * p<0.05 ; * * p<0.01$. 
of E-selectin were significantly increased by 24 -h treatment with $20-33 \mathrm{~mm}$ glucose (Fig. 2A) or with $30-100 \mu \mathrm{M}$ PUGNAc (Fig. 2C). The cell surface levels of E-selectin were also significantly enhanced by $24-48$-h treatment with $33 \mathrm{~mm}$ glucose (Fig. 2B) and by $12-24-\mathrm{h}$ treatment with $100 \mu \mathrm{M}$ PUGNAc (Fig. 2D).

E-Selectin expression is enhanced by stimulation with proinflammatory cytokines such as IL- $\beta$ and TNF- $\alpha$ on vascular endothelial cells. We investigated whether high glucose and PUGNAc enhance E-selectin expression additively to IL$1 \beta$ stimulation in HuH-7 cells (Fig. 3). The E-selectin levels on the surface were enhanced significantly by 24-h stimulation with $100 \mathrm{U} / \mathrm{ml} \mathrm{IL}-1 \beta$ in $\mathrm{HuH}-7$ cells. Treatment for $24 \mathrm{~h}$ with $33 \mathrm{~mm}$ glucose or $100 \mu \mathrm{M}$ PUGNAc resulted in even higher levels of E-selectin expression. The expression of Eselectin reached a plateau by these treatments and the additive effects on those of IL- $1 \beta$ were not observed.

High Glucose and PUGNAc Modulate Promoter Activities of CRE and AP-1 in HuH-7 Cells To determine whether high glucose and PUGNAc modulate the promoter activities of CRE and AP-1, we transfected $\mathrm{HuH}-7$ cells with CRE and AP-1 reporter genes and determined their promoter activities using a dual luciferase assay (Fig. 4). We found that 24-h treatment with $33 \mathrm{~mm}$ glucose or $100 \mu \mathrm{M}$ PUGNAc significantly suppressed the CRE promoter activity and enhanced AP-1 promoter activity, respectively (Figs. 4A, B).

We next examined whether PUGNAc can modulate signaling to $\mathrm{CRE}$ and $\mathrm{AP}-1$ promoter activities to investigate the effects of $O$-GlcNAcylation (Fig. 5). HuH-7 cells transfected with pCRE-Luc and treated with $100 \mu \mathrm{M}$ PUGNAc for $24 \mathrm{~h}$ were then stimulated with $100 \mu \mathrm{M}$ dibutyryl cAMP for $3 \mathrm{~h}$. Since dibutyryl cAMP enhances PKA-dependent phosphorylation of CREB, the CRE promoter activity was enhanced 7 fold. This enhanced CRE promoter activity was suppressed

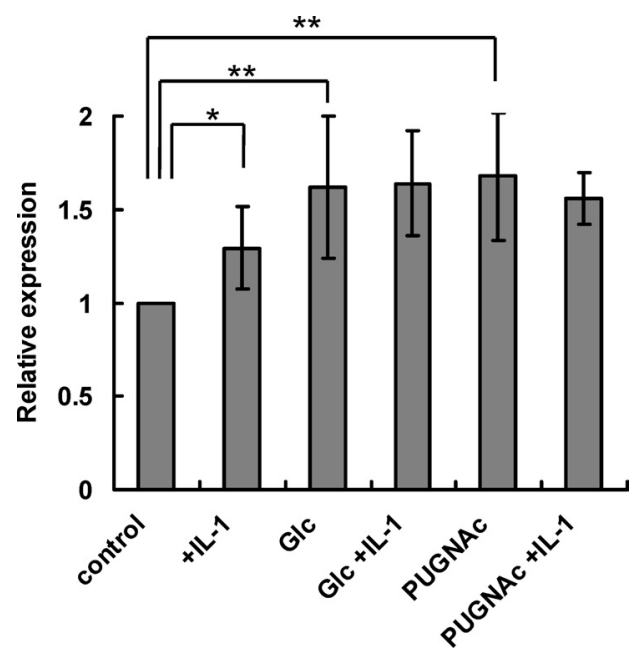

Fig. 3. Effect of IL-1 $\beta$ on Cell Surface Levels of E-Selectin in HuH-7 Cells Pretreated with High Glucose or PUGNAc

HuH-7 cells were treated with $100 \mathrm{U} / \mathrm{ml} \mathrm{IL}-1 \beta$ for $24 \mathrm{~h}$ or with $33 \mathrm{~mm}$ glucose or $100 \mu \mathrm{m}$ PUGNAc for $24 \mathrm{~h}$, followed by $100 \mathrm{U} / \mathrm{ml}$ IL- $1 \beta$ for $24 \mathrm{~h}$. Cell surface levels of E-selectin were determined as described in Fig. 2. The results represent means \pm S.D. $(n=4) . * p<0.05 ; * * p<0.01$.
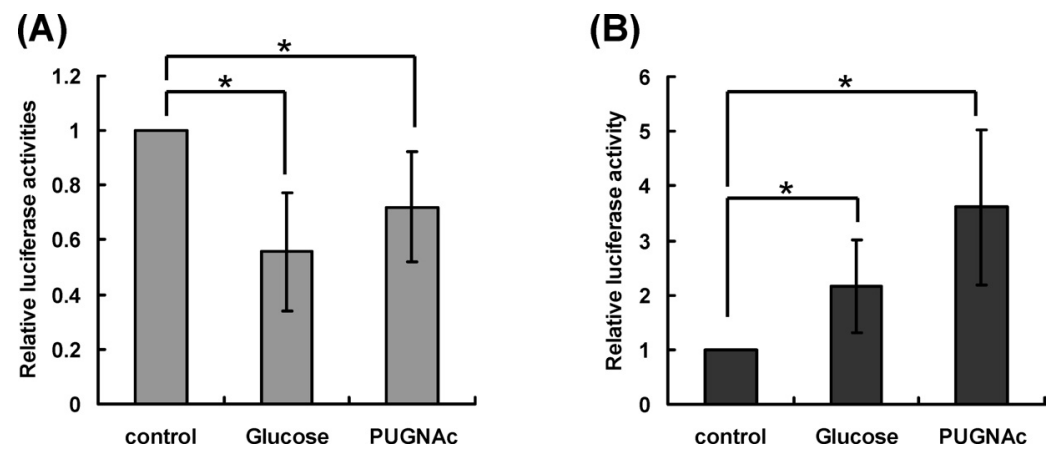

Fig. 4. Dual Luciferase Assay for CRE and AP-1 Promoter Activities in HuH-7 Cells Treated with High Glucose or PUGNAc

HuH-7 cells were co-transfected with pCRE-Luc or pAP-1-Luc and pRL-CMV and treated with 33 mM glucose or $100 \mu \mathrm{M}$ PUGNAc for $24 \mathrm{~h}$. Luciferase activities were determined using a dual luciferase assay system then pCRE-Luc (A) and pAP-1-Luc (B) were normalized to those in cells without glucose and PUGNAc. Data are expressed as means \pm S.D. $(n=3)$. Significant differences $(p<0.05)$ are indicated with asterisks $(*)$.
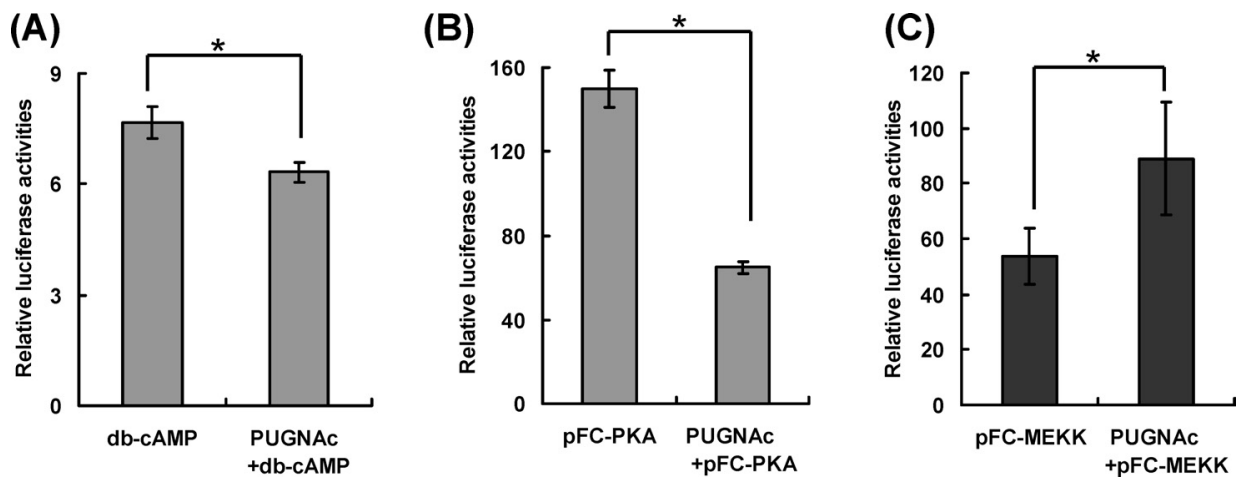

Fig. 5. Activation-Induced CRE and AP-1 Promoter Activities in HuH-7 Cells Treated with PUGNAc

(A) HuH-7 cells transfected with pCRE-Luc and pRL-CMV and treated with $100 \mu \mathrm{M}$ PUGNAc for $24 \mathrm{~h}$ were activated with $100 \mu \mathrm{M}$ dibutyryl cAMP for $3 \mathrm{~h}$. The cells were cotransfected with pCRE-Luc and pFC-PKA (B) or with pAP-1-Luc and pFC-MEKK (C) and treated with $100 \mu \mathrm{M}$ PUGNAc for $24 \mathrm{~h}$. Luciferase activities were measured in HuH-7 cells by dual luciferase assay. The values were normalized to those in cells without PUGNAc. Data are expressed as means \pm S.D. $(n=3)$. Significant differences $(p<0.05)$ are indicated with asterisks $(*)$. 
by PUGNAc (Fig. 5A).

For further investigation of PKA-dependent CRE promoter activation, we co-transfected $\mathrm{HuH}-7$ cells with pCRE-Luc and PKA expression vector pFC-PKA then treated the cells with $100 \mu \mathrm{M}$ PUGNAc for $24 \mathrm{~h}$. We found that pFC-PKA markedly enhanced CRE promoter activity and that this enhanced promoter activity was significantly suppressed by PUGNAc (Fig. 5B). To estimate MEKK-dependent promoter activation, we co-transfected $\mathrm{HuH}-7$ cells with pAP-1-Luc and MEKK expression vector $\mathrm{pFC}-\mathrm{MEKK}$ then treated the cells with $100 \mu \mathrm{M}$ PUGNAc for $24 \mathrm{~h}$. AP-1 promoter activity was also increased by $\mathrm{pFC}-\mathrm{MEKK}$, and this effect was further enhanced by PUGNAc (Fig. 5C). These results suggest that high glucose and PUGNAc enhanced E-selectin expression by decreasing CRE promoter activity and increasing AP-1 promoter activity.

PUGNAc Accumulates $O$-GlcNAcylated CREB in Nuclear Extracts We next examined whether $O$-GlcNAcylation of CREB prevents nuclear translocation or promoter activity in HuH-7 cells. The cells were treated for $24 \mathrm{~h}$ with $100 \mu \mathrm{M}$ PUGNAc, and $O$-GlcNAcylated proteins in the cytoplasmic and nuclear extracts were detected by immuno-blotting using an anti-O-GlcNAc antibody (Fig. 6). Multiple $O$ GlcNAcylated protein bands were detected in the whole cell extracts and PUGNAc accumulated $O$-GlcNAcylated proteins (Fig. 1). As shown in Fig. 6A, the patterns of $O$-GlcNAcylated bands were different in the cytoplasmic and nuclear extracts from $\mathrm{HuH}-7$ cells treated with PUGNAc. The $O$ GlcNAcylated protein bands were distributed broadly in the cytoplasmic extract and between 30 and $60 \mathrm{kDa}$ in the nu-

(A)

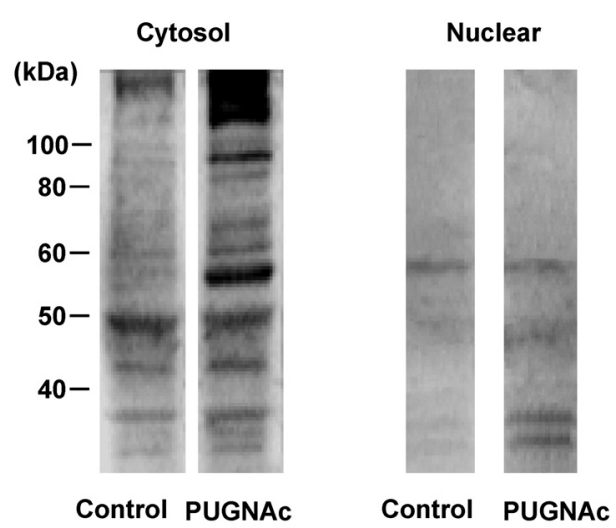

(B)

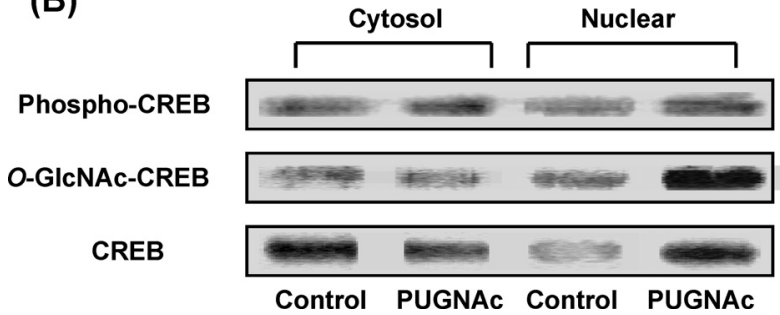

Fig. 6. Levels of $O$-GlcNAcylated and $O$-Phosphorylated CREB in Cytoplasmic and Nuclear Fractions of HuH-7 Cells Treated with PUGNAc

(A) Cytoplasmic and nuclear extracts were obtained from $\mathrm{HuH}-7$ cells treated with $100 \mu \mathrm{m}$ PUGNAc for $24 \mathrm{~h}$, and $O$-GlcNAcylated proteins in the extracts were immunoblotted using an anti-O-GlcNAc antibody and POD-conjugated secondary antibody. (B) CREB in cytoplasmic and nuclear extracts was immunoprecipitated using an antiCREB antibody and immuno-blotted using anti-O-GlcNAc and anti-phospho CREB antibodies. clear extract.

We further examined the nuclear transport of $O$-GlcNAcylated and phosphorylated CREB. After treating HuH-7 cells with $100 \mu \mathrm{M}$ PUGNAc for $24 \mathrm{~h}$, we immuno-precipitated CREB from cytoplasmic and nuclear extracts with antiCREB antibody and immuno-blotted using anti-O-GlcNAc or anti-phospho-CREB antibodies (Fig. 6B). We found that PUGNAc caused a decrease in the CREB levels in the cytoplasmic fraction and a marked increase in the level in the nuclear fraction. Furthermore, the increase in CREB in the nuclear fraction was mostly due to an increase in the $O$ GlcNAcylated form. These results suggest that PUGNAc enhanced $O$-GlcNAcylation and nuclear transport of CREB.

\section{DISCUSSION}

High concentrations of glucose enhance the hexosamine biosynthetic pathway, and increasing the $O$-GlcNAcylation of proteins that modulate intracellular signaling involves Ser/Thr phosphorylation. In the present study, we investigated the effects of $O$-GlcNAcylation on the promoter activities of CRE and AP-1, which are reported to regulate E-selectin gene expression. Cell surface levels of E-selectin were significantly increased in $\mathrm{HuH}-7$ cells by high glucose or PUGNAc. IL-1 $\beta$ also enhanced E-selectin expression, but the effects were not additive to those of glucose and PUGNAc.

Many transcription factors have been reported to regulate expression of adhesion molecules. ${ }^{19,25-27)}$ In our preliminary study, we found that high glucose and PUGNAc enhanced Eselectin but not VCAM-1 and ICAM-1 expression in HuH-7 cells. ATF-2 is a specific transcription factor regulating E-selectin expression and interacts with CREB and c-Jun. Thus we considered whether high glucose and PUGNAc modulate CRE and AP-1-regulated promoter activities.

We determined the effects of high glucose and PUGNAc on the promoter activities of $\mathrm{CRE}$ and AP-1 using $\mathrm{HuH}-7$ cells transfected with reporter plasmids pCRE- and pAP-1Luc. Our results indicate that high glucose and PUGNAc suppress CRE promoter activities and enhance AP-1 promoter activities. Also, enhanced CRE promoter activities by stimulation with the PKA activator dibutyryl cAMP and cotransfection of PKA expression vector were significantly suppressed by PUGNAc. We further cotransfected HuH-7 cells with pAP-1-Luc and the MEKK expression vector $\mathrm{pFC}$ MEKK and determined the AP-1 promoter activities following PUGNAc treatment. In contrast, AP-1 promoter activities were increased in pFC-MEKK cotransfected $\mathrm{HuH}-7$ cells and were further enhanced by PUGNAc.

The CRE/ATF-2 element (TGACATCA) in the promoter of E-selectin (NF-ELAM1) differs from the consensus CRE binding site (TGACGTCA) by a single nucleotide $(\mathrm{G} \rightarrow \mathrm{A}){ }^{20}$ ) CREB competitively regulates the formation of c-Jun and ATF-2 heterodimer, suppressing the E-selectin promoter response to $\mathrm{CAMP}^{21)} \mathrm{A}$ heterodimer of c-Jun and ATF-2 is constitutively bound to the NF-ELAM1 site. TNF- $\alpha$ stimulates c-Jun N-terminal kinase and p38 MAP kinase, which phosphorylate c-Jun and ATF-2, respectively, enhancing Eselectin expression. ${ }^{24)}$ Many transcriptional factors are $O$ GlcNAcylated including CREB, c-Jun, and c-Fos. ${ }^{28,29)} O$ GlcNAcylation of CREB impairs its ability to bind ATF-2 and reduces transcriptional activity. ${ }^{30)}$ Our results also show 
that PUGNAc accumulates $O$-GlcNAcylated CREB in nuclear and suppresses the promoter activity of CRE. Enhancement of AP-1 promoter activity by PUGNAc might also be involved $O$-GlcNAcylation of c-Jun.

We demonstrated that the patterns of $O$-GlcNAcylated proteins are quite different between cytoplasmic and nuclear extracts; the cytoplasmic proteins are distributed broadly, whereas those in the nucleus are between 30 and $60 \mathrm{kDa}$. PUGNAc treatment time-dependently increases $O$-GlcNAcylation of protein kinase B (Akt 1) and nuclear accumulation but GlcNAcylated glycogen synthase kinase $3 \beta$ dose not import into the nucleus. ${ }^{31)} O$-GlcNAcylated proteasome blocks all proteasomal ATPase activity, specifically prevents chymotryptic activity, and is linked with the stability of transcription factors such as Sp 1. ${ }^{32)} O$-GlcNAcylated $\mathrm{Sp} 1$ is rapidly translocated from cytoplasm to nucleus, where the transcriptional activity of Sp 1 is obligatory for phosphorylation. $^{33)}$ It has been reported that trafficking of macromolecules between the cytoplasm and nucleus is mediated by nuclear pore complex. ${ }^{34)}$ Macromolecules $>40 \mathrm{kDa}$ are actively transported into the nucleus through the nuclear pore complex, and smaller molecules can diffuse between the two compartments. Numerous nuclear lectins have been shown to participate in the nuclear transport of glycosylated proteins. ${ }^{35)}$ Consistent with this, our immunoprecipitation studies revealed that $O$-GlcNAcylated CREB is actively transported into the nucleus. This adds to the accumulating evidence that $O$-GlcNAcylation plays an important role in the nuclear transport of proteins.

The level of cell surface E-selectin is regulated by the degradation of protein in addition to its synthesis. Recently, Ahmad et al. reported the phosphorylation and $O$-GlcNAcylation sites in the cytoplasmic domain of E-selectin in silico. $^{36)}$ They suggested that $O$-GlcNAc modification of Eselectin regulates its stability by controlling its half-life, although we did not confirm the $O$-GlcNAcylation of Eselectin in this study.

In this report, we demonstrated that high glucose and PUGNAc suppress CRE promoter activity and enhance AP-1 promoter activity in hepatocytes. We also showed that enhanced E-selectin expression might be induced by decrease in $O$-GlcNAcylated CREB binding and increase in $O$-GlcNAcylated c-Jun binding to ATF sites at NF-ELAM of E-selectin promoter region.

Acknowledgements This study was supported in part by the "Open Research Center" Project from the Ministry of Education, Culture, Sports, Science and Technology (MEXT) of Japan.

\section{REFERENCES}

1) Comer F. I., Hart G. W., Biochim. Biophys. Acta, 1473, 161-171 (1999).

2) Whelan S. A., Hart G. W., Circ. Res., 93, 1047-1058 (2003).

3) Guinez C., Morelle W., Michalski J. C., Lefebvre T., Int. J. Biochem. Cell Biol., 37, 765-774 (2005).

4) Wells L., Vosseller K., Hart G. W., Science, 291, 2376-2378 (2001).

5) Zachara N. E., Hart G. W., Biochim. Biophys. Acta, 1761, 599-617
(2006).

6) Iyer S. P. N., Hart G. W., Biochemistry, 42, 2493-2499 (2003).

7) Zachara N. E., Hart G. W., Biochim. Biophys. Acta, 1673, 13-28 (2004).

8) Hanover J. A., FASEB J., 15, 1865-1876 (2001).

9) Bagg W., Ferri C., Desideri G., Gamble G., Ockelford P., Braatvedt G. D., J. Clin. Endocrinol. Metab., 86, 5491-5497 (2001).

10) Leinonen E., Hurt-Camejo E., Wiklund O., Hulten L. M., Hiukka A., Taskinen M. R., Atherosclerosis, 166, 387-394 (2003).

11) Morigi M., Angioletti S., Imberti B., Donadelli R., Micheletti G., Figliuzzi M., Remuzzi A., Zoja C., Remuzzi G., J. Clin. Invest., 101, 1905-1915 (1998).

12) Omi H., Okayama N., Shimizu M., Okouchi M., Ito S., Fukutomi T., Itoh M., J. Diabetes Complications, 16, 201-208 (2002).

13) Okayama N., Omi H., Okouchi M., Imaeda K., Kato T., Akao M., Imai S., Shimizu M., Fukutomi T., Itoh M., J. Diabetes Complications, 16, $321-326$ (2002).

14) Itoh M., Omi H., Okouchi M., Imaeda K., Shimizu M., Fukutomi T., Okayama N., J. Diabetes Complications, 17, 22-26 (2003).

15) Piconi L., Quagliaro L., Da Ros R., Assaloni R., Giugliano D., Esposito K., Szabo C., Ceriello A., J. Thromb. Haemost., 2, 1453-1459 (2004).

16) Higai K., Shimamura A., Matsumoto K., Clin. Chim. Acta, 367, 137143 (2006)

17) Cai D., Yuan M., Frantz D. F., Melendez P. A., Hansen L., Lee J., Shoelson S. E., Nat. Med., 11, 183-190 (2005).

18) Lautamaki R., Borra R., Iozzo P., Komu M., Lehtimaki T., Salmi M., Jalkanen S., Airaksinen K. E., Knuuti J., Parkkola R., Nuutila P., Am. J. Physiol. Endocrinol. Metab., 291, E282-E290 (2006).

19) Collins T., Read M. A., Neish A. S., Whitley M. Z., Thanos D., Maniatis T., FASEB J., 9, 899-909 (1995).

20) Kaszubska W., Hooft van Huijsduijnen R., Ghersa P., DeRaemySchenk A. M., Chen B. P., Hai T., DeLamarter J. F., Whelan J., Mol Cell Biol., 13, 7180-7190 (1993).

21) De Luca L. G., Johnson D. R., Whitley M. Z., Collins T., Pober J. S., J. Biol. Chem., 269, 19193-19196 (1994).

22) Horsch M., Horsch L., Vasella A., Rast D. M., Eur. J. Biochem., 197, $815-818$ (1991).

23) Haltiwanger R. S., Grove K., Philipsberg G. A., J. Biol. Chem., 273, $3611-3617$ (1998)

24) Lefebvre T., Ferreira S., Dupont-Wallois L., Bussiere T., Dupire M. J., Delacourte A., Michalski J. C., Caillet-Boudin M. L., Biochim. Biophys. Acta, 1619, 167-176 (2003).

25) Whitley M. Z., Thanos D., Read M. A., Maniatis T., Collins T., Mol. Cell Biol., 14, 6464-6475 (1994).

26) Read M. A., Whitley M. Z., Gupta S., Pierce J. W., Best J., Davis R. J., Collins T., J. Biol. Chem., 272, 2753-2761 (1997).

27) Neish A. S., Read M. A., Thanos D., Pine R., Maniatis T., Collins T., Mol. Cell Biol., 15, 2558-2569 (1995).

28) Tai H. C., Khidekel N., Ficarro S. B., Peters E. C., Hsieh-Wilson L. C., J. Am. Chem. Soc., 126, 10500-10501 (2004).

29) Khidekel N., Ficarro S. B., Peters E. C., Hsieh-Wilson L. C., Proc. Natl. Acad. Sci. U.S.A., 101, 13132-13137 (2004).

30) Lamarre-Vincent N., Hsieh-Wilson L. C., J. Am. Chem. Soc., 125, $6612-6613$ (2003).

31) Gandy J. C., Rountree A. E., Bijur G. N., FEBS Lett., 580, 30513058 (2006).

32) Zhang F., Su K., Yang X., Bowe D. B., Paterson A. J., Kudlow J. E., Cell, 115, 715-725 (2003).

33) Majumdar G., Harrington A., Hungerford J., Martinez-Hernandez A., Gerling I. C., Raghow R., Solomon S., J. Biol. Chem., 281, 36423650 (2006).

34) Stewart M., Baker R. P., Bayliss R., Clayton L., Grant R. P., Littlewood T., Matsuura Y., FEBS Lett., 498, 145-149 (2001).

35) Monsigny M., Rondanino C., Duverger E., Fajac I., Roche A. C., Biochim. Biophys. Acta, 1673, 94-103 (2004).

36) Ahmad I., Hoessli D. C., Gupta R., Walker-Nasir E., Rafik S. M., Choudhary M. I., Shakoori A. R. Nasir-ud-Din., J. Cell Biochem., 100, $1558-1572$ (2007). 